\title{
THE EFFECTIVENESS OF ENGLISH SONGS IN TEACHING PRONUNCIATION TO ELEMENTARY SCHOOL STUDENTS IN SD BINTANG PERTIWI
}

\author{
${ }^{1 *}$ Hermansyah, ${ }^{2}$ Cici Handayani, and ${ }^{3}$ Dewi Wulandari \\ ${ }^{1,2,3}$ Politeknik Unggul LP3M, Medan, Indonesia \\ *Corresponding author: hermansyahlmb@gmail.com
}

\begin{abstract}
The objective of this research is to find out the effectiveness of using English songs in teaching pronunciation to elementary students with descriptive method. Descriptive method was taken from the description of the situation of the object based on the fact in the field. Meanwhile, the research design which was conducted in this research was classroom action research design by Miles and Hubermann (2010). Based on the research result and discussion, the use of English songs as the media in teaching pronunciation to the students in SD Bintang Pertiwi, the students' ability in pronouncing English words has improved significantly. Songs were used as media because the lyrics of the song were easy to memorize. Therefore, it is possible for the students to comprehend the words they have listened and pronounced. English songs are effective to use as media in teaching pronunciation to elementary students. There is a significant improvement of students' ability in pronouncing English words.
\end{abstract}

Keywords: effectiveness, teaching, pronunciation, song

\section{Introduction}

The successful of mastering English to elementary students depends on the role of English teachers. Teaching English as a foreign language has different pronunciation from their mother tongue. Certainly, these factors make the elementary students have the problem in pronouncing the English words. On the other hand, it is found that the teacher uses the traditional technique in teaching English. Therefore, students' ability in learning English especially in pronunciation is not good enough.

Pronunciation is a person's ability to comprehend the sound system which has direct effect of the word meaning in the language. One of the techniques to teach pronunciation for elementary studens is using songs as the media.

A song can be used to practice the pronunciation which is kept in the brain memory unconsciously. This situation creates a relax and amusing learning process in a class. If the students feel relax and amusing in a learning process, the students are well motivated to learn the correct pronunciation. Therefore, the researcher conducted the research to find out how to teach pronunciation and whether English songs are 
effective to use as media in teaching pronunciation to the elementary student at SD Bintang Pertiwi.

\section{Literature Review \\ Definition of the Effectiveness}

The word effective comes from English word which is defined as a thing that has been done well. The effectiveness is the main element to achieve a goal or target in each organization, activity or a program. It is called effectiveness if the goal or the target is achieved.

According to Kurniawan (2005: 109), effectiveness is the ability to do a work or a function without a force in the process. Meanwhile, Sondang (2008: 4) defines effectiveness is the use of resource, facilities and infrastructure in certain quantity to get a number of products consciously. In addition, Ravianto (2014) explains that effectiveness is how well a work is done and produces the expected output. It means that if a work can be finished by good planning whether the time or the cost, it is called effective.

Based on the experts' opinion above, it can be concluded that effectiveness is the ability to use well the resource, facilities and infrastructure to produce the expected output by good planning.

Another expert, Muasaroh (2010: 13) states that the effectiveness can be measured by some aspects:

1. The function aspect

A program is called effective if it is done well. For example, a learning program is called effective if the function is done well and the learners have the good learning situation.

2. The planning aspect

A program is called effective if the program is planned well. So, the learning program will be effective if it is planned well.

3. The rules aspect

The effectiveness of a program can be measured by the rules which will be done well so that the program occurs as planned.

4. The objective aspect

If the objective of a program has been achieved well, it is called effective for example in learning process. The objective of a learning process has been achieved well by seeing the students' success in learning.

\section{The Concept of Song \\ English Songs}

Songs are teaching materials that teacher can use with young learners. Songs can be used in variety of ways. Lo and Li (1998) stated that songs play a significant role in motivating students to learn English. Singing songs and listening to music are enjoyable for learners. They are more relaxed and attentive than usual and therefore more receptive to learning. Songs can be motivated and captive the attention of 
foreign language learners. They can support the development of the ability of a learner to read, write, listen and speak as well as providing opportunity for learning pronunciation.

In this study, the researchers convince that song can offer new ways to improve students' skill in learning English and carry students into pleasure activities without reduce discipline of learn.

A song is a short piece of music with words that are sung by human being. It is not possible to separate a song and the music which constitute a complete unity to create a beautiful art. Rasyid (2010) explains that a song can be used as an effective media in learning process for elementary students. By singing, the students will study happily and have motivation to study actively.

\section{Songs in the Classroom}

Songs in the classroom are a wonderful way to learn. English Song is one of the general media that very useful to be used in teaching.: Everyone likes listening to music and song cannot only be fun for students. When it is fun, students can find English not a difficult subject so it can be used in an effective to students in elementary school.

There are many researches that have proved that using songs in learning English processes is a very useful tool. Morales (2008) considers that when students sing, they may improve English their speaking skills and practice pronunciation. In addition, the students can discuss the different topics in the lyrics like love, hate, revenge, and in this manner, they can practice speaking by expressing opinions and reflections about the contents of the songs.

According to Orlova (2003) these are some of the advantages for working in class with songs:

1. Practicing the rhythm, stress and the intonation patterns of the English language.

2. Teaching vocabulary, especially in the vocabulary reinforcement stage.

3. Teaching grammar. In this respect, songs are especially favored by teachers while investigating the use of the tenses.

4. Teaching speaking. For this purpose, songs and mainly their lyrics are employed as a stimulus for class discussions.

5. Teaching listening. Music can be helpful for comprehension.

6. Developing writing skills. For this purpose, a song can be used in a variety of ways; for example, speculation as to what could happen to the characters in the future, writing a letter to the main character, etc.

The same thought as Suprijono (2003: 23) which stated that the use of English songs as learning media can stimulate the learners to practice the language skill.

Those explanations give us some conclusions that music is the universal language and children respond very strongly to song. Singing together with other children, a teacher 
or another adult, is a pleasure activity for children. It is a fun way for children learning English to increase their skill in English. It can be a valuable resource to help teach language and share culture at the same time. Music is a strong resource which helps create positive feelings about English. While songs serve as useful teaching tools for EFL students, they also contribute to helping create a positive and warm atmosphere in the English learning environment. The use of songs in learning process is considered as an effective media to stimulate the students to improve their language skills and also the students can learn actively.

\section{Pronunciation}

Pronunciation is defined as the way in which a language is spoken (Hornby, 995: 497). On the other hand, Dalton (1998: 3) defines pronunciation as the production of significant sound in two senses. First, sound is significant because it is used as a part of a code of a particular language. Second, sound is significant because it is used to achieve meaning in contexts of use. Another statement comes from Kristina (2007: 1) who defines pronunciation as the production and reception of sounds of speech and the achievement of the meaning. It means that the words, phrases, and sentences being pronounced should be intelligible.

Based on the statements above, it can be concluded that pronunciation is the production and reception of sound of speech that happen in speaking and listening the words, phrases and sentences so that it is meaningful.

Pronunciation is one of the important aspects in English, especially in oral communication. Every sound, stress pattern, and intonation may convey meaning. The non-native speakers of English who speak English have to be very careful in pronouncing some utterances or he may create misunderstanding.

\section{English Songs and Pronunciation}

Pronunciation is the way we pronounce a word, especially in a way that is accepted or generally understood. The way we speak also conveys something about ourselves to the people around us.

Why is pronunciation of English words difficult?

- As languages differ in their range of sounds, students have to learn to 'physically' produce certain sounds previously unknown to them.

- Learners can find sounds difficult to pick out, and may not see the point in focusing on them.

However, mispronouncing words creates miscommunication, for it can be a different intepratation for the listener.

How songs can help?

1. Songs are authentic and easily accessible examples of spoken English. The rhymes in songs provide listeners with repetition of similar sounds. 
2. Students often choose to listen to songs time and again, indirectly exposing them to these sounds.

Learners with good pronunciation are more likely to be understood even if they make errors in other areas. Pronunciation also includes attention to the particular sounds of language and aspects of speech beyond the individual sounds, such as; intonation, stress, rhythm, vowel and consonants, voiced and voiceless" sounds.

\section{The Characteristics of Elementary School Students}

The characteristic of elementary school students in teaching English is not the same as teaching adult. Elementary school students usually consist of students about six up to twelve years old who are relatively mature children with an adult side and a childish side. Their characteristics and motivation are different with students at the higher levels, like junior high school and university. Some people say that children learn language faster than adult. This perhaps is influenced by the plasticity of a young brain.

The characteristics of students in elementary school are as follows:

1. They are competence user of mother tongue

2. Typical of elementary school students is curiosity.

3. They need to inspect, to know, to organize, and to classify.

4. They were expected to act as adults in every way, and they did so.

5. They can tell the difference between the fact and fiction

6. They love to play and learn best when they enjoy themselves, but they also take themselves seriously and like to think that what they are doing is real work.

7. They are enthusiastic and positive about learning.

8. They rely on the spoken words as well as the physical word to convey and understanding meaning.

9. They are able to work with other and learn from other.

10. Their own understanding comes through eyes, hands and ears.

Based on the characteristics of elementary school students above, it can be sure that the teachers have important role for elementary school students. The roles of the teachers are:

1. Making the children the center of learning. As Montessori Said, "The teacher's task is not to talk, but to prepare and arrange a series of motives for cultural activity in a special environment made for the child" (George, 1988: 85).

2. Encouraging children to use the freedom provider for them.

3. Observing children so as to prepare the best possible environment, recognizing sensitive periods, and diverting unacceptable behavior to meaningful tasks.

4. As teachers, we can capitalize on our students' natural curiosity and help them expand it by introducing them to new topics (Kenneth, 984: 22).

\section{Research Method \\ Research Design}


The descriptive method is used as the research method. It is used to describe the situation of the object based on the fact in the field. Meanwhile, the research design which will be used in this research is classroom action research design which has four steps:

\section{Planning}

After finding the problem in the field, the researcher identified the problem found in the field and planned some ways to overcome the problem. In this research, the problem found was the lack of the elementary students' ability to pronounce English words well, meanwhile, the way was used to overcome the problem was the use of English songs as a learning media. So, in this step, the researcher prepared lesson plan, teaching media, observation sheet and field note.

2. Action

After planning to use English songs as learning media to the elementary students, the researcher asked the English teachers as the researcher collaborators to use the media during the learning process in the classroom based on the lesson plan that is written by the researcher. It means that the researcher conducted the treatment to the elementary students.

3. Observing

In this step, the researcher observed the process of the treatment and note the things which occured in the field in observation sheet and field note.

4. Reflecting

The researcher and the collaborators discussed the result of the treatment, the things that had been achieved, the obstacles faced and also the solution for those obstacles to be used in the next cycle.

\section{Technique and Instruments of Data Collection}

Technique of Data Collection will apply in this research are measurement and observation. In measurement, the researcher will measure the students' performances result in each cycle through speaking assessment where students are asked to answer the questions related to English Song orally one by one in front of the class through alphabetize. Meanwhile, in observation, the writer observed the students' performance by using observation checklist and alphabetize.

There are four Tools of Data Collection used in this research, namely Speaking Assessment, Field Note, and observation Checklist. In Field Note, the researcher will ask the collaborator to write down and record the students' speaking ability and students' behavior started from the first to the third cycle. Observation Checklist contains the list of objectives that the research collaborator will check when observe the activity in the classroom. Observation checklist will become the guideline for the researcher to give the specific feedback on aspects of the classroom.

\section{Technique of Data Analysis}

The technique of data analysis will use the qualitative research technique in which Miles and Hubermann (2010) stated that the data analysis consists of three activities such as:

1. Data reduction 
Data reduction is the process of selecting, focusing, simplifying, abstracting and transforming the raw data. In other words, data reduction is the process of minimizing the data required. Here, the researcher selected the data required discard the data which did not concern to the research

2. Data display

Data display is the process of organizing the data. Here, the researcher arranged the data which consisted of some documents.

3. Conclusion drawing

Conclusion drawing will be done after analyzing the data display. Here, the researcher interpreted the result of data display and concluded the result of this research.

\section{Result and Discussion}

\section{Research Result}

The Learning Activity before Using The English Songs as Media

Before using the English songs as media to teach the pronunciation, the researchers had conducted the first observation to the research subject. The first observation was done in July 20, 2017 at SD Bintang Pertiwi whereby the research subject is the fifthgrade students. The observation took place in the classroom where the teacher taught the students around 80 minutes.

Based on the first observation, it was found that the students had the difficulty in pronouncing English word when the teachers asked them for reading some passages in their text book. There were many words which were spelled incorrectly so the teacher had to correct the students' pronunciation.

\section{Learning Activity after Using English Songs as Media for the First Cycle}

The learning activity for the first cycle was conducted on the $3^{\text {rd }}$ of August 2017 and on the $7^{\text {th }}$ of August 2017. The research leader had the responsibility to the research execution. The research members had the role to observe and note the research execution by filling in the field note and speaking assessment. In this research, the English teacher who still taught the English but the teacher had to teach the English by using the lesson plans which had been designed by the researchers.

The first meeting of the first cycle was conducted on the $3^{\text {rd }}$ of August 2017. It was Friday. The English lesson began at 08.15 a.m. First, The English teacher began the class by greeting the students. The next, the teacher asked the students for praying. One of the students led the praying. After that the English teacher introduced the researcher to the students and told what the researcher would do in their class. Then the teacher explained the material that would be taught today based the lesson plan which had been designed by the researchers. The teacher told the students that today they would sing together and also practice their pronunciation by using the lyric of the song. The text of the song was distributed to the students. Then, the teacher played the video of the song "If You're Happy and You Know It" once and the students watched and listened to song. The next, the teacher invited the students to sing together. After singing together, the teacher asked the students one by one to read 
the lyric of the song. In this occasion, the researchers observed and noted the pronunciation of each student to see their ability in pronouncing the lyric of the song "If You're Happy and You Know It". All students got their turn to read the lyric of the song. Based on the observation, there were only four students who could pronounce well the lyric of the song that the teacher asked for reading. Meanwhile, the seventeen students had still many errors in pronouncing the lyric of the song. After reading, the students were invited to sing the song together and also moved the body in accordance with the gesture in the video of the song "If You're Happy and You Know It". The students enjoyed singing the song and moving their bodies. The class ended at 09.40 a.m.

The second meeting of the first cycle was conducted on the $7^{\text {th }}$ of August 2017. As usual, the English teacher greeted the students. The teacher began the class. It was still the same scenario whereby the teacher showed a video of the song entitled "Old MacDonald Had a Farm" which had fast tempo and the students were asked for watching and listening to the song. The teacher played the video once. After that, the teacher invited the students to sing together. And after singing together, the students were asked for reading the lyric of the song one by one to see their ability in pronouncing the English words. Meanwhile the researchers observed and noted the students' ability in pronouncing lyric of the song. At this day, there were six students who were able to pronounce well with minimal errors. The rest still had many errors in pronouncing lyric of the song. After reading the lyric of the song, the students are invited to sing together cheerfully because the song had fast rhythm. The students were very enthusiastic. Before ending the class, the teacher reminded the students to sing the previous song that was sung last week and asked whether one of the students could sing the song without text. But nobody could sing the song without text. So, the teacher asked if one of the students could sing the song "If You're Happy and You Know It" by text individually. No student liked to do that. So, the teacher asked the students for singing in group. And there were three students who liked to sing the song. Although they sang slowly and they might feel shy, but the teacher appreciated their performance well and their friends gave applause to them. And the class ends at 9.35 a.m.

Based on the observation of the first cycle, it was found that the students were very enthusiastic in learning English particularly using English songs to improve their pronunciation. It could be seen by speaking assessment sheet at the second meeting in which there were six students who could pronounce well the lyric of the song with minimal errors.

\section{Summary of the First Cycle}

Based on the observation and the speaking assessment sheet during the first cycle, it is concluded that:

1. The students' ability in pronouncing the English words is still low. It is based on the speaking assessment sheet which indicates that there are only six students who can pronounce the lyric of the songs well with minimal errors. 
2. The students have not been accustomed yet with the learning activity using English song as media.

Therefore, the researchers consider that the result of the first cycle has not achieved the target that has been set. There are only $28 \%$ of the students who can pronounce well the lyric of the song. Meanwhile, the target of this research is $60 \%$ of the students can pronounce well the lyric of the English song.

\section{Learning Activity after Using English Songs as Media for the Second Cycle}

The second cycle was held on the $17^{\text {th }}$ and $20^{\text {th }}$ of August 2017 . The scenario of the second cycle was still the same as the first cycle.

The first meeting of the second cycle was on $17^{\text {th }}$ of August 2017. It was Friday morning. As usual, the English lesson began at 8.25 a.m. The teacher said "good morning" to the students and the next one of the students led the praying. On that day, the students would watch a video of the song entitled "Twinkle- Twinkle Little Star". At that moment, the students were enthusiastic enough because they are familiar with this song. First, the students watched and listened to the song once. Each student has the text of the song on their hands. After watching the video, the students sang the song together. And then, the students were asked to read the lyric of the song one by one accordance with the attendance list. In that time, there was a good progress whereby most students could pronounce the lyric well. There were only three students who had still many errors in pronouncing lyric of the song "TwinkleTwinkle Little Star", six students had several errors and eleven students pronounced the lyric of the song accurately. Nevertheless, the students kept enthusiastic on singing the song together until at the end of the learning program. The class ended at 9.40 a.m.

For the second meeting which was taken place on the $20^{\text {th }}$ of August 2017, the researchers prepared three songs at once. The songs were Twinkle- Twinkle Little Star, Old Mac Donald Had a Farm and If You're Happy and You Know It. These songs were the songs that had been watched and listened by the students at the previous meetings. For the second meeting, researchers also noted the students' progress in pronouncing the lyric of the three songs. Based on the speaking assessment, it was obtained that there was only one student who had still many errors in pronouncing the lyric of the song well. Meanwhile, the students who had several errors in pronouncing the lyric of the songs were six students. And there were fourteen students who could pronounce the lyric of the songs accurately.

\section{Summary of the Second Cycle}

Based on the observation and the speaking assessment sheet during the second cycle, it is concluded that:

1. The students' ability in pronouncing the English words has improved. It is based on the speaking assessment sheet which indicates that there are fourteen students who can pronounce the lyric of the songs accurately. 
2. The students have been accustomed with learning activity using English song as media and the students enjoy learning English using songs.

\section{Discussion}

After conducting this research at SD Bintang Pertiwi which took place from the $3^{\text {rd }}$ $24^{\text {th }}$ August 2017, the researchers found that English songs are affective to improve the students' ability in pronouncing English words. The improvement of the students' ability in pronouncing English words can be seen by the following table.

Table 1. The Result of The Use English Songs

\begin{tabular}{|l|c|c|c|c|}
\hline \multicolumn{1}{|c|}{ Cycle } & \multicolumn{2}{c|}{ Cycle 1 } & \multicolumn{2}{c|}{ Cycle 2 } \\
\hline Date & $03-08-2017$ & $10-08-2017$ & $17-8-2017$ & $24-8-2017$ \\
\hline Number of students & 4 & 6 & 11 & 14 \\
\hline Percentage & $19 \%$ & $28 \%$ & $52 \%$ & $67 \%$ \\
\hline
\end{tabular}

Based on the table above, it can be seen that there is a significant improvement of the students' ability in pronouncing English words after using English songs as a media in teaching pronunciation to the fifth-grade students at SD Bintang Pertiwi. At the first cycle, the improvement of students' ability in pronouncing English words is from $19 \%$ to $28 \%$. Meanwhile, at the second cycle, the improvement is from $52 \%$ to $67 \%$. Therefore, the researchers did not continue the next cycle because the percentage has denoted that there are $67 \%$ of students that has pronounced well the English words after using English songs in learning activity.

\section{Conclusions}

Based on the research results and discussion, it is concluded that:

1. By using English songs as the media in teaching pronunciation to the students, the students' ability in pronouncing English words improve. Songs is used as media because the lyric of the song is easy to memorize. So, it is possible for the students to memorize the words that they have said.

2. English songs are effective to use as media in teaching pronunciation to the elementary students at SD Bintang Pertiwi because there is a significant improvement of students' ability in pronouncing English words.

\section{References}

Brown, H.D. (2008). Language Assesment, Principles and Classroom Practice. White Plains, NY: Pearson Education.

Chen, Su (2006). EFL teachers' perceptions of English language policy at the elementary level in Taiwan. Educational Studies, 32(3), 265-283.

Christoper, Rust (2003). How to do Action Research in Your Classroom: Lesson from Teachers Network Leadership Institude. Retrieved

Cohen, L., \& et al. (2005). Research Methods in Education. 5th

Cuesta, M. (2006). Songs in the English Class: A Strategy to Encourage Tenth

Curtain and Dahlberg. (2004). Use of Songs, Rhymes and Games in Teaching English to Young Learners in Bangladesh. Dhaka University Journal of Linguistic, 2(3), 161172.

Dalton, C., \& Seidlhofer, B. (1998). Pronunciation. Oxford: Oxford University Press. 
Proceedings of the $1^{\text {st }}$ Annual International Conference on Language and Literature, 18-19 April 2018, Fakultas Sastra, UISU, Medan, Indonesia.

George, Moririson. (2008). Early Childhood Education Today. USA: Merill Publishing Company.

Griffee, D.T. (2001). Song in Action. Hertfordshire: Prentice Hall International.

Hornby, AS. (1995). Oxford Advanced Learner's Dictionary of Current English.

Kristina, Diah. (2007). Pronunciation 1. Surakarta: UNS Press.

Kurniawan, Agung. (2005). Transformasi Pelayanan Publik. Yogyakarta: Pembaruan.

Lado, R. (2010). Language Teaching. A scientific Approach. Bombay-New Delhi: Tata McGraw-Hill Publshing Co.Itd.

Lo, R. \& Li, H.C. (1998), Songs Enhance Learner Involvement. English Teaching Forum, $36,8-11$

McCarthy, J. (2006). Songs in The Classroom. TESOL. Courses.

Miles, Mathew \& Michael Hubermann. (2010). Qualitative Data Analysis: A Sourcebook of New Methods. London: Sage Publication, Inc.

Morales, Rosana. (2008). Empowering Your Pupils Through Role-Playing Exploring Emotions and Building Resilence. New York. Routledge.

Muasaroh, Siti. (2010). Pengertian dan Landasan Efektivitas.Jakarta: Bumi Aksara.

Nunan, D. (2003). Practical English Language Teaching. New York: Mc Gravo Hill.

Orlova. (2003). Efektifitas Program Penanggulangan Pengangguran Karang Taruna "Eka Taruna Bhakti" Desa Sumerta Kelod Kecamatan Denpasar Timur Kota Denpasar.Input, vol. 2 (1): 49-57

Ramelan. (1985). English Phonetics. Semarang: IKIP Semarang Press.

Rasyid, Fathur. (2010). Cerdaskan Anakmu dengan Musik, Yogyakarta: Diva Press

Ravianto, J. (2014). Manajemen Personalia dan Sumber Daya Manusia. Yogyakarta: BPFE

Sondang, Siagian. (2008). Teori dan Praktek Kepemimpinan. Yogyakarta. Rineka Cipta.

Suprijono. (2010). Sistem Pengendalian Manajemen. Yogyakarta: Diva Press 